\title{
miR-622 Suppresses Tumor Formation by Directly Targeting VEGFA in Papillary Thyroid Carcinoma [Retraction]
}

\author{
Wang R, Ma Q, Ji L, Yao Y, Ma M, Wen Q. Onco Targets \\ Ther. 2018;11:1501-1509.
}

The Editor and Publisher of OncoTargets and Therapy wish to retract the published article. The journal was notified of alleged image manipulation relating to Figure 3B. Specifically:

- Figure 3B panel miR-NC appears to be a duplication, but with more cells added, of Figure 7B panel siCON group published in Wang et al, 2017 (https:// doi.org/10.1159/000480412).

- The same image has also been observed in other publications, including Figure 11a panel miR-708 mimic, published in Song et al, 2019 (https://doi. org/10.1007/s12253-017-0334-z) and in Figure 8B published in Pan et al, 2018 (RETRACTED) (https://doi.org/10.1159/000487567).

The authors were unable to provide a satisfactory explanation for the duplication and the decision was made to retract the paper.

Our decision-making was informed by our policy on publishing ethics and integrity and the COPE guidelines on retraction.

The retracted article will remain online to maintain the scholarly record, but it will be digitally watermarked on each page as "Retracted".

\section{Publish your work in this journal}

OncoTargets and Therapy is an international, peer-reviewed, open access journal focusing on the pathological basis of all cancers, potential targets for therapy and treatment protocols employed to improve the management of cancer patients. The journal also focuses on the impact of management programs and new therapeutic agents and protocols on patient perspectives such as quality of life, adherence and satisfaction. The manuscript management system is completely online and includes a very quick and fair peer-review system, which is all easy to use. Visit http://www.dovepress.com/ testimonials.php to read real quotes from published authors. 